Historical perspective

\title{
Speciation, stability, and coagulation mechanisms of hydroxyl aluminum clusters formed by PACl and alum: A critical review
}

\author{
Hongxiao Tang, Feng Xiao, Dongsheng Wang* \\ State Key Laboratory of Environmental Aquatic Chemistry, Research Center for Eco-Environmental Sciences, Chinese Academy of Sciences, POB 2871, Beijing 100085, China
}

\section{A R T I C L E I N F O}

\section{Available online 25 September 2015}

\section{Keywords:}

Alum cluster

Coagulation

Hydrolysis

Modified DLVO

Speciation

\begin{abstract}
A B S T R A C T
The physicochemical property of coagulant species plays a significant role in the coagulation process. Recent progress on speciation, stability, and coagulation mechanisms of the hydroxyl aluminum clusters formed by $\mathrm{PACl}$ and alum has been critically reviewed. The complicated nature on species formation, stability, and transformation of various hydrolyzed aluminum clusters formed by PACl and Alum are discussed. Based on the aspects of spontaneous hydrolysis, forced hydrolysis, and dual-hydrolysis models, the special stability of aluminum clusters that results in various coagulation behaviors is compared with the traditional salts. The coagulation behavior of the hydroxyl aluminum clusters in terms of particle aggregation and restabilization, surface adsorption and coverage, microfloc formation and kinetics, modified DLVO simulation, and finally, the coagulation model is then analyzed in detail. It is indicative that the coagulation mechanism of inorganic coagulants can be understood better with the hydroxyl clusters being tailor-made.
\end{abstract}

(c) 2015 Elsevier B.V. All rights reserved.

\section{Contents}

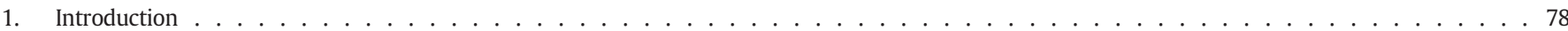

2. Chemical speciation of hydroxyl aluminum clusters . . . . . . . . . . . . . . . . . . . . . . . . . . . . . . . 79

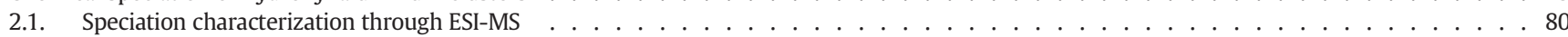

2.2. ${ }^{27} \mathrm{Al}$ NMR combined with Ferron assay . . . . . . . . . . . . . . . . . . . . . . . . . . . . 80

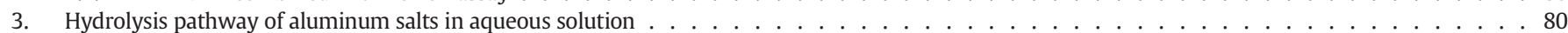

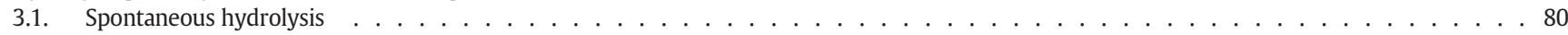

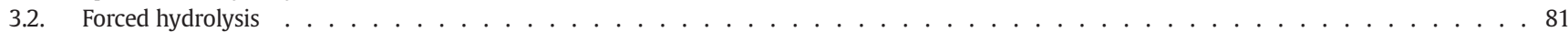

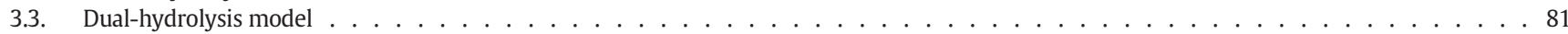

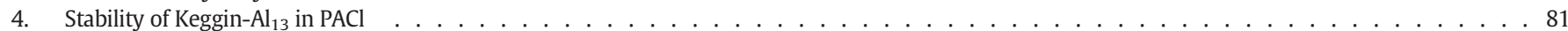

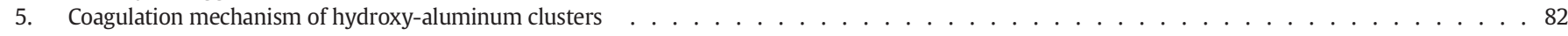

5.1. Adsorption and surface coverage . . . . . . . . . . . . . . . . . . . . . . . . . . . . . 82

5.2. Coagulation of silica microspheres suspension . . . . . . . . . . . . . . . . . . . . . . . 82

5.3. Microfloc aggregation and simplified DLVO simulation _ . . . . . . . . . . . . . . . . . . . . . . . . 82

5.4. Morphological observation . . . . . . . . . . . . . . . . . . . . . . . . . . . . . 82

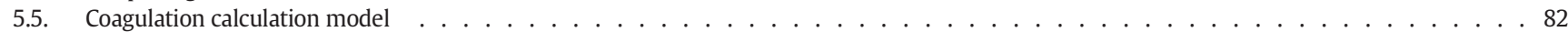

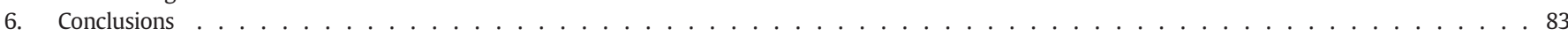

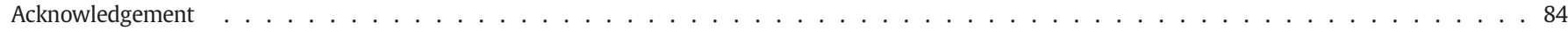

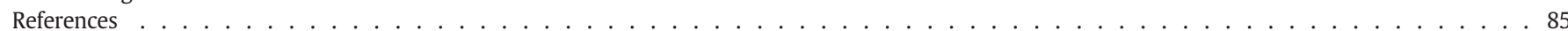

\section{Introduction}

Aqueous chemistry of hydroxyl aluminum clusters, involving the comprehensive hydrolysis processes and the formulation of polymeric species, has been a permanent and controversial subject in many fields

\footnotetext{
* Corresponding author.

E-mail address: wgds@rcees.ac.cn (D. Wang).
}

of science and technology. It is widely concerned both in geochemical, medical, environmental sciences, and many industrial applications such as pharmaceutical, petroleum, ceramic, catalysis, and other areas [1-5]. It is also closely related with the coagulation and flocculation process in water and wastewater treatment especially with the recent development and application of novel inorganic polymer flocculants (IPFs). Basically, there are two major types of IPFs, i.e. cationic type including polyaluminum chloride (PACl), polyaluminum sulfate (PAS), 
polymeric ferric sulfate (PFS), and polymeric ferric chloride (PFC), and anionic type including polymeric silicates. In addition, complex coagulants such as polymeric ferroaluminium chloride (PAFC) and polyaluminum silicate chloride (PASiC) have also emerged as a new type of IPFs receiving much attention. The development of IPFs is now becoming a series of coagulant productions, where the Al-based varieties are dominating among them [1]. The details of IPFs are shown in Table 1.

However, many arguments remained obviously on the chemical species and structures of the hydrolyzed aluminum clusters or polymers, and even more arguments on the proposed model of their formation pathways [2,6-9]. The first step towards resolving these knotty problems would be a comprehensive understanding of chemical speciation information obtained by a battery of analytical techniques under various experimental conditions. In recent years, due to the great contribution of the advanced instrumentations such as ${ }^{27} \mathrm{Al} \mathrm{NMR}$ and ${ }^{17} \mathrm{O}$ MAS NMR, SAXS, ESI Q-TOF-MS, and Ferron assay, the speciation, structure, and transformation of hydroxyl aluminum clusters have been more clearly defined [2,5-12]. The effect of the sulfate ion on coagulation indicated that sulfate had a significantly different effect on PACl coagulation as a result of performed hydrolysis products, where charge neutralization and precipitation play different parts in the coagulation process [7]. Based on the kinetic difference of the reactions between the aluminum and ferron agent, the ferron method enables one to partition soluble aluminum species into such categories as monomeric, fast-reacting polymeric, or slow-reacting colloidal species denoted simply as $\mathrm{Al}_{\mathrm{a}}, \mathrm{Al}_{\mathrm{b}}, \mathrm{Al}_{\mathrm{c}}$, respectively [9].

Meanwhile, the general mechanisms of coagulation have been summarized recently in Duan and Gregory's review in detail [13]. There are two distinct mechanisms in the coagulation process: charge neutralization of negatively charged colloids and incorporation of impurities in an amorphous hydroxide precipitate. The relative importance of these mechanisms depends on factors such as $\mathrm{pH}$ and coagulant dosage. Due to the low solubility of aluminum, with increase of alum dosage, excessive aluminum hydroxide precipitation can form, and particles in water can be enmeshed by the hydroxide precipitate. This process is the so-called "sweep flocculation." Chowdhury and Amy [14] claimed that precipitation is the main mechanism in the coagulation of alumina colloids with alum. According to the "sweep flocculation" model, the incorporation of colloids into precipitate follows two pathways: one is the heterogeneous nucleation involving charge neutralization and subsequent growth of precipitate at low $\mathrm{pH}$ value, and the other is homogeneous nucleation involving precipitation and subsequent particle aggregation at high $\mathrm{pH}$. With respect to the coagulation/flocculation mechanisms of PACls, most current studies focused on the mode of charge neutralization [15-18]. Dentel $[11,17]$ had tried to explain the coagulation mechanisms of different kinds of coagulants by a combined model of precipitation charge neutralization (PCN). Recently, "electrostatic patch coagulation" was proposed by Wang et al. [18] to interpret the coagulation behaviors of PACls, but it has not been examined systematically using controlled experiments in detail. The experimental results showed that there exists a remarkable difference in coagulation with various $\mathrm{PACl}$ formulation in accordance with the different species

Table 1

Category and series of inorganic polymer flocculants.

\begin{tabular}{llll}
\hline Cationic & & Inorganic composite & \\
\hline Poly Al chloride & PACl, ACH & $\mathrm{Al}+\mathrm{Fe}+\mathrm{OH}+\mathrm{SO}_{4}$ & PAFS \\
& & $\mathrm{Al}+\mathrm{Fe}+\mathrm{OH}+\mathrm{Cl}$ & PAFC \\
Poly Al sulfate & PAS & $\mathrm{Al}+\mathrm{Si}+\mathrm{OH}+\mathrm{Cl}$ & PASi \\
Poly Fe sulfate & $\mathrm{PFS}$ & $\mathrm{Fe}+\mathrm{Si}+\mathrm{OH}+\mathrm{Cl}$ & $\mathrm{PFSi}$ \\
Poly Fe chloride & $\mathrm{PFC}$ & $\mathrm{Fe}+\mathrm{OH}+\mathrm{PO}_{4}$ & $\mathrm{PFP}$ \\
Poly Al phosphate & $\mathrm{PAP}$ & $\mathrm{Inorg}+$ Org Composite & \\
Anionic & & $\mathrm{PACl}+$ Anionic Polymer & \\
Poly-silicate & $\mathrm{PSi}$ & $\mathrm{PACl}+$ Nonionic Polymer & \\
Activated silica & $\mathrm{ASi}$ & $\mathrm{PACl}+$ Cationic Polymer & \\
& & $\mathrm{PACl}+$ Chitosan & \\
\hline
\end{tabular}

being performed. This indicates that the assumption of all the surface species consisting of the same aluminum hydroxide solids is not correct, and some modification of the PCNM is therefore needed [18].

In fact, the hydroxyl aluminum clusters in $\mathrm{PACl}$ products are intermediate product during the hydrolysis-polymerization-precipitation process of $\mathrm{Al}(\mathrm{III})$ ions under specific conditions. A large amount of investigation and practical application show that the $\mathrm{AlO}_{4} \mathrm{Al}_{12}(\mathrm{OH})_{24}^{7+}$ ( $\mathrm{sim}-$ plified as $\mathrm{Al}_{13}$ ) is the most efficient species in PACl coagulant [1-11, 19-23]. The $\mathrm{Al}_{13}$ polycatin also has a number of industrial applications, including use as a flocculant in waste water treatment, as a primary constituent of pharmaceutical and cosmetic products, and ceramics [8]. However, the significance of $\mathrm{Al}_{13}$ in the coagulation process might be undermined by the transformation reaction after dosing into real water. Therefore, the stability of $\mathrm{Al}_{13}$ under various water quality conditions should be clarified. Moreover, the coagulation behavior of the $\mathrm{Al}_{13}$ in terms of particle aggregation and restablization, microfloc formation, kinetics, and modeling needs to be addressed. The $\mathrm{Al}_{13}$ polymer and polyaluminum chloride $(\mathrm{PACl})$ were comparatively investigated for the coagulation of humic acid (HA). The results showed that the floc properties were essentially dependent on $\mathrm{pH}$. Compared to $\mathrm{PACl}, \mathrm{Al}_{13}$ polymer displayed better stability and functioned more rapidly after addition, and the flocs formed by $\mathrm{Al}_{13}$ were denser across the $\mathrm{pH}$ values investigated.

The structure of hydroxyl aluminum clusters in coagulants not only is important in understanding the basic chemical aspects of coagulation but also has a great impact on the practical operation level of coagulation. However, a comprehensive understanding of aluminum speciation in coagulation involves multidisciplinary methods and knowledge. This paper focuses on the following three aspects: (1) to summarize the methodology involved in aluminum speciation and the hydrolysis models of aluminum clusters under different situation, (2) to reveal the distinct coagulation mechanism of PACl by comparing its behavior with the alum's, (3) to provide coagulation calculation models for $\mathrm{PACl}$, the future development tendency and the compatibility of tailormade PACl coagulants with following process such as microfloc filtration, flotation, membrane separation.

\section{Chemical speciation of hydroxyl aluminum clusters}

The study on chemical speciation of aqueous aluminum hydroxyl clusters has achieved significant progress in recent years $[1,2,6]$. It was contributed by the concurrent utilization of the advanced instrumental techniques like NMR, SAXS, PCS, ESI Q-TOF MS, and Ferron assay.

The comprehensive formula for Al-hydroxyl species can be written as $\mathrm{Al}_{\mathrm{x}}(\mathrm{OH})_{\mathrm{y}}\left(\mathrm{H}_{2} \mathrm{O}\right)_{\mathrm{n}}^{(3 \mathrm{x}-\mathrm{y})+}$ or $\mathrm{Al}_{\mathrm{x}} \mathrm{O}_{\mathrm{z}}(\mathrm{OH})_{\mathrm{y}}\left(\mathrm{H}_{2} \mathrm{O}\right)_{\mathrm{n}}^{(3 \mathrm{x}-\mathrm{y}-2 \mathrm{z})+}$. Their classification may be exemplified in Table 2 , in which the oligomers are limited and denoted only as $\mathrm{Al}_{2}$ and $\mathrm{Al}_{3}$ clusters to show their special importance. The $\mathrm{Al}_{\mathrm{a}}, \mathrm{Al}_{\mathrm{b}}$, and $\mathrm{Al}_{\mathrm{c}}$ are the categories of species defined by Ferron assay.

The ${ }^{27} \mathrm{Al}$ NMR spectroscopy is the most useful technique to identify the hydroxyl $\mathrm{Al}(\mathrm{III})$ species according to the response peak at specific chemical shift $(\delta, \mathrm{ppm})$ on the spectrum. The four-fold coordinated tetrahedral $\mathrm{Al}(\mathrm{III})$ can be observed at the range above $\delta=60 \mathrm{ppm}$ and the six-fold coordinated octahedral $\mathrm{Al}(\mathrm{III})$ is below $\delta=20 \mathrm{ppm}$. Generally,

Table 2

Aqueous hydroxyl Al(III) species.

\begin{tabular}{lll}
\hline Degree of polymerization & Possible chemical formula & Ferron assay \\
\hline Monomer & $\mathrm{Al}^{3+}, \mathrm{Al}(\mathrm{OH})^{2+}, \mathrm{Al}(\mathrm{OH})_{2}^{+}, \mathrm{Al}(\mathrm{OH})_{4}^{-}$ & $\mathrm{Al}_{\mathrm{a}}$ \\
Oligomer & $\mathrm{Al}_{2}(\mathrm{OH})_{2}^{4+}, \mathrm{Al}_{2}(\mathrm{OH})_{5}^{+}, \mathrm{Al}_{3}(\mathrm{OH})_{4}^{++}$ & \\
Low-mer & $\mathrm{Al}_{6}(\mathrm{OH})_{12}^{6+}, \mathrm{Al}_{6}(\mathrm{OH})_{15}^{3+}, \mathrm{Al}_{8}(\mathrm{OH})_{20}^{4+}$ & $\mathrm{Al}_{\mathrm{b} 1}$ \\
Mid-mer & $\mathrm{Al}_{13}(\mathrm{OH})_{32}^{7+}, \mathrm{Al}_{13} \mathrm{O}_{4}(\mathrm{OH})_{24}^{7+}\left(\mathrm{Al}_{13}\right)$ & $\mathrm{Al}_{\mathrm{b} 2}$ \\
High-mer & $\mathrm{Al}_{15}(\mathrm{OH})_{36}^{9+}, \mathrm{Al}_{30} \mathrm{O}_{8}(\mathrm{OH})_{56}^{15+}\left(\mathrm{Al}_{30}\right)$ & \\
Sol, gel & $(\mathrm{Al} 13)_{\mathrm{n}}, \mathrm{Al}^{+}(\mathrm{OH})_{3}{ }^{\mathrm{a}}$ & $\mathrm{Al}_{\mathrm{c}}$ \\
Precipitates & {$\left[\mathrm{Al}(\mathrm{OH})_{3}\right]_{\mathrm{n}}{ }^{\mathrm{a}}$} & \\
\hline
\end{tabular}

a $\mathrm{Al}(\mathrm{OH})_{3(\mathrm{~s})}$ is very special depending on preparation mode and coagulation experiments. 
sharp peaks refer to the responses of monomer $\mathrm{Al}_{1}(\delta=0 \mathrm{ppm})$, tridecamer $\mathrm{Al}_{13}(\delta=62.5 \mathrm{ppm})$. The responses of oligomers $\mathrm{Al}_{2}, \mathrm{Al}_{3}$ are difficult to distinguish from that of monomer [1,2]. In recent years, the polycation $\mathrm{Al}_{30}$ has been observed and assigned in high-temperature conditions $[19,20]$. Both $\mathrm{Al}_{13}$ and $\mathrm{Al}_{30}$ can be identified due to their tetrahedral $\mathrm{Al}(\mathrm{O})_{4}$ core in Keggin structure that yields diagnostic peaks in ${ }^{27} \mathrm{Al} \mathrm{NMR}$ spectra. So far, the responses on the ${ }^{27} \mathrm{Al} \mathrm{NMR}$ spectrum to be identified are listed in Table 3 .

In Table 3, the clusters of $\mathrm{Al}(\mathrm{O})_{6}$ series beyond $\mathrm{Al}_{3}$ with the structure of pure octahedral cannot be assigned accurately by ${ }^{27} \mathrm{Al} \mathrm{NMR}$ due to their broad peak responded. Originally, the pure octahedral species with the six-member ring structure were suggested as their basic configuration. This structure was proposed on the core-link theory and the building block of aluminum hydroxide gel. It has been accepted by mainly geochemists for many years. However, their existence was suspected and arguable for decades due to lacking of definitive instrumental identity other than potentiometry. In recent years, the hexamer $\mathrm{Al}(\mathrm{O})_{6}$ clusters were more clearly identified by using the SAXS [10], ab initio molecular dynamics [6], and other methods [24]. These studies demonstrated the existence of the hexamer clusters in solution according to the molecular size determination and structural computation.

\subsection{Speciation characterization through ESI-MS}

The ESI-MS showed some other promise. Feng et al. had improved the method for identification of Al species in ESI-MS spectrum [25, 26]. The general formula for identification of $\mathrm{Al}$ species form was $\left[\mathrm{Al}_{\mathrm{x}} \mathrm{O}_{\mathrm{y}}(\mathrm{OH})_{\mathrm{z}}\left(\mathrm{H}_{2} \mathrm{O}\right)_{\mathrm{m}}\right]^{(2 \mathrm{y}+\mathrm{z}-3 \mathrm{x})+}$. In the mass spectrum, the intensity of peaks often form many independent Gaussian-shaped clusters, shown by the cure. Al species identified from these peaks in one Gaussian-shaped cluster often have the same polymerization degree. The peaks in each cluster splitting at 18,9 , and 5 show that the positive charges of $+1,+2$, and +3 were identified from Al species. No chloride ligands were present in the formula as a result of the volatile of chlorine in neutralization and desolvation process.

Oligomeric species such as $\mathrm{Al}_{1}, \mathrm{Al}_{2}, \mathrm{Al}_{3}, \mathrm{Al}_{4}$, and $\mathrm{Al}_{5}$ were observed in ESI-MS of $\mathrm{AlCl}_{3}$, while high polymeric species of $\mathrm{Al}_{13}, \mathrm{Al}_{16}, \mathrm{Al}_{19}$, and $\mathrm{Al}_{20}$ were presented in their purified Keggin- $\mathrm{Al}_{13}$ spectrum. They also proposed that $\mathrm{Al}_{13}$ with three type of charges $(+1,+2$, and +3$)$ was directly transformed from Keggin- $\mathrm{Al}_{13}^{7+}$ in the original solution. The decrease of the charges from +7 to $+1,+2$, and +3 should be mainly ascribed to the fragmentation of hydrogen ligands in the structure of Keggin- $\mathrm{Al}_{13}^{7+}$ during the nebulization and desolvation process in mass analyzer. Most of these species have also been identified in many former studies.

Besides, another series of aqueous aluminum clusters of pure $\mathrm{Al}(\mathrm{OH})_{6}$ octahedras were synthesized and isolated. "Flat" molecular species are favored when the synthesis conditions result in slow hydrolysis, such as oxidation of a metal in an acidic solution or in the presence of trapping or chelating ligands. These $\mathrm{Al}(\mathrm{O})_{6}$ clusters with $6,8,13,15$, and $32 \mathrm{Al}$ atoms have been previously synthesized and structurally characterized, respectively [24,27-29]. They are most commonly synthesized with an aminocarboxylate ligand but also found in purely inorganic solutions as well. The new identified $\mathrm{Al}(\mathrm{O})_{6}$ clusters are different in structure from six-member-ring configuration. They are so-called flat-series and constructed upon a repeated set of cubane-like moieties arrayed in a lattice of edgeshared but with an octahedra core. The flat- $\mathrm{Al}_{13}\left[\mathrm{Al}_{13}(\mathrm{OH})_{24}^{15+}\right]$ with the structure of pure $\mathrm{Al}(\mathrm{O})_{6}$ is also an $\mathrm{Al}$ tridecamer but different from either Keggin- $\mathrm{Al}_{13}\left[\mathrm{AlO}_{4} \mathrm{Al}_{12}(\mathrm{OH})_{24}^{7+}\right]$ or six-member ring $\mathrm{Al}_{13}\left[\mathrm{Al}_{13}(\mathrm{OH})_{32}^{7+}\right]$. A schematic illustration of the proposed structure of hydroxyl polymeric aluminum species is shown in the Table 4 [1].

\section{2. ${ }^{27}$ Al NMR combined with Ferron assay}

The structure of isolated flat clusters is a little different from the hypothetical six-member ring series with the central octahedral core. Nevertheless, both of them are pure $\mathrm{Al}(\mathrm{O})_{6}$ structure and unassignable by ${ }^{27} \mathrm{Al}$ NMR due to the quadrupole broadening nature of aluminum atoms. To distinguish the species of pure $\mathrm{Al}(\mathrm{O})_{6}$ structure, the method other than ${ }^{27} \mathrm{Al}$ NMR should be applied.

A new idea has been carried out to distinguish these species. The reactive $\mathrm{Al}_{\mathrm{b}}$ was further divided into $\mathrm{Al}_{\mathrm{b} 1}$ as $\mathrm{Al}(\mathrm{O})_{6}$ species and $\mathrm{Al}_{\mathrm{b} 2}$ as Keggin- $\mathrm{Al}_{13}$ according to their different reaction rate with Ferron $[8,9$, 30-32]. The key difference between $\mathrm{Al}_{\mathrm{b} 1}$ and $\mathrm{Al}_{\mathrm{b} 2}$ was that the reaction kinetic constant of $\mathrm{Al}_{\mathrm{b} 1}$ was an order of magnitude higher than that of $\mathrm{Al}_{\mathrm{b} 2}$. Less discrepancy was observed by using $\mathrm{Al}_{\mathrm{b} 2}$ instead of $\mathrm{Al}_{\mathrm{b} 2}$ to compare with the Keggin- $\mathrm{Al}_{13}$, which confirmed this speculation. It was demonstrated by this combined procedure that the $\mathrm{Al}_{\mathrm{b} 1}$ series of $\mathrm{Al}(\mathrm{O})$ ${ }_{6}$ clusters actively existed at the area of $\mathrm{B}(=\mathrm{OH} / \mathrm{Al}$ ratio $)$ around $0.5-$ 1.5 and the Keggin- $\mathrm{Al}_{13}$ clusters dominated at $\mathrm{B}$ above $1.0-2.5$. Then the position of $\mathrm{Al}(\mathrm{O})_{6}$ clusters in the system of hydroxy-aluminum can be determined along the ${ }^{27} \mathrm{Al}$ NMR spectrogram or even $\mathrm{B}[\mathrm{OH} / \mathrm{Al}$ ratio] sequence.

The K-value assay was based on the assumption that the reactions between Ferron and aluminum species conform to psedudo-firstorder, and thus an equation could be applied to simulate the reaction:

$\mathrm{Al}_{\mathrm{t}}=\mathrm{Al}_{0}+\mathrm{Al}_{\mathrm{b} 1}\left(1-\exp \left(-\mathrm{k}_{1} \mathrm{t}\right)\right)+\mathrm{Al}_{\mathrm{b} 2}\left(1-\exp \left(-\mathrm{k}_{2} \mathrm{t}\right)\right)+\mathrm{Al}_{\mathrm{c}}$

Generally, the mononuclear aluminum and Ferron was regarded to react instantaneously, and $\mathrm{Al}_{\mathrm{c}}$ was inert to Ferron in this reaction. Ye et al. calculated the $\mathrm{k}$ value of $\mathrm{PACl}$ with various basicities and proposed that the $\mathrm{k}_{1}$ value of $\mathrm{Al}(\mathrm{O})_{6}$ fractions falls into a range of $(0.82$ $18.89) \times 10^{-3} \mathrm{~s}^{-1}$ and $\mathrm{k}_{2}$ value of Keggin- $\mathrm{Al}_{13}$ falls into a range of $(0.09-0.87) \times 10^{-3} \mathrm{~s}^{-1}$ shown in Table 5 [30]. This could be used as a quantitative criteria to distinguish the species of different structures.

\section{Hydrolysis pathway of aluminum salts in aqueous solution}

\subsection{Spontaneous hydrolysis}

When the $\mathrm{Al}$ (III) salts are added and dissolved in aqueous solution, the hydrolysis reaction occurs spontaneously. This type of hydrolysis carries out automatically as a result of the typical aqueous chemical equilibrium. There will be firstly the transformation between the mononuclear complexes according to the corresponding $\mathrm{pH}$ and $\mathrm{Al}$ concentration.

$\mathrm{Al}^{3+} \rightleftarrows \mathrm{Al}(\mathrm{OH})_{2}{ }^{+} \rightleftarrows \mathrm{Al}(\mathrm{OH})^{2+} \rightleftarrows \mathrm{Al}(\mathrm{OH})_{3}{ }^{0} \rightleftarrows \mathrm{Al}(\mathrm{OH})_{3(\mathrm{am})} \rightleftarrows \mathrm{Al}(\mathrm{OH})_{4}{ }^{-}$

The reaction inclines to precipitate at a rather low level of Al concentration. However, the polynuclear clusters with double hydroxyl bridges need to be formed before the precipitation takes place. The primary

Table 3

Possible responses of Al clusters on ${ }^{27} \mathrm{Al}$ NMR spectrum.

\begin{tabular}{|c|c|c|c|c|c|c|c|c|c|}
\hline$A l_{x}$ & $\mathrm{Al}_{1}$ & $\mathrm{Al}_{2}$ & $\mathrm{Al}_{3}$ & $\mathrm{Al}_{6}$ & $\mathrm{Al}_{6}-\mathrm{Al}_{13}$ & $\mathrm{Al}_{6}-\mathrm{Al}_{30}$ & $\mathrm{Al}_{13}$ & $\mathrm{Al}_{30}$ & $\mathrm{Al}(\mathrm{OH})_{4}^{-}$ \\
\hline$\delta p p m$ & 0 & $2-3$ & 5 & $10-12$ & $10-12$ & $12-15$ & 62.5 & 70 & 80 \\
\hline$n$ & $\mathrm{Al}(\mathrm{O})_{6}$ & $\mathrm{Al}(\mathrm{O})_{6}$ & $\mathrm{Al}(0)_{6}$ & $\mathrm{Al}(\mathrm{O})_{6}$ & $\mathrm{Al}(0)_{6}$ & $\mathrm{Al}(0)_{6}$ & $\mathrm{Al}(\mathrm{O})_{4}$ & $\mathrm{Al}(\mathrm{O})_{4}$ & $\mathrm{Al}(\mathrm{O})_{4}$ \\
\hline
\end{tabular}


Table 4

The structure of hydroxyl polymeric aluminum determined by single crystal.

\begin{tabular}{|c|c|c|c|}
\hline \multicolumn{2}{|l|}{$\mathrm{Al}(\mathrm{O})_{6}$} & \multicolumn{2}{|l|}{$\mathrm{Al}(\mathrm{O})_{4}$} \\
\hline Poly-degree & Polyhedron & Poly-degree & Polyhedron \\
\hline $\mathrm{Al}_{2}$ & & $\varepsilon-\mathrm{K}^{-\mathrm{Al}_{13}}$ & \\
\hline $\mathrm{Al}_{8}$ & & $\delta-\mathrm{K}^{-\mathrm{Al}_{13}}$ & \\
\hline $\mathrm{M}-\mathrm{Al}_{13}$ & & $\mathrm{Al}_{30}$ & \\
\hline
\end{tabular}

dimers and trimers may be transformed further to the oligomers and polymers,

$\mathrm{Al}(\mathrm{OH})_{2}{ }^{+} \rightarrow \mathrm{Al}_{2}(\mathrm{OH})_{2}{ }^{4+} \rightarrow \mathrm{Al}_{3}(\mathrm{OH})_{5}{ }^{4+} \rightarrow \mathrm{Al}_{6}(\mathrm{OH})_{12}{ }^{6+} \rightarrow \mathrm{Al}_{13}(\mathrm{OH})_{32}{ }^{7+} \rightarrow \mathrm{Al}_{\mathrm{x}}(\mathrm{OH})_{\mathrm{y}}{ }^{(3 \mathrm{x}-\mathrm{y})+}$

Owing to the change of solution $\mathrm{pH}, \mathrm{Al}$ concentration, or aging, the transformation course will proceed further. The hydrolysis and polymerization reactions will go along alternately. When it reaches to a certain degree, the hydrolysis will be preferable to enter the polymerization stage because the increasing charges become strong enough to obstruct further access of the clusters. The net charge of the polymers will decrease due to further hydroxylation and then the precipitation will finally happen. The turning point is likely at the range of $\mathrm{OH} / \mathrm{Al}=2.2 \sim 2.5$ and the maximum for the net charge could not be too high.

\subsection{Forced hydrolysis}

The Keggin- $\mathrm{Al}_{13}$ species are considered as the most active coagulating components in $\mathrm{PACl}$ products. They are yielded in the special operational conditions either in laboratory by base titration or in the industrial production stage by dissolution of aluminum minerals. These processes generally adopted an intensive way of neutralization involving strong acid or base. In the mild spontaneous hydrolysis condition, it is difficult to produce the clusters like Keggin- $\mathrm{Al}_{13}$ with a tetrahedral core. This is because the transform of double hydroxyl link (olation) between $\mathrm{Al}$ atoms to oxygen link (oxylation) or from the octahydral coordination to tetrahydral is promoted to occur at the higher $\mathrm{pH}$ and

Table 5

The K-value criteria of $\mathrm{PACl}$ with different basicities.

\begin{tabular}{lll}
\hline Sample & \multicolumn{2}{l}{ K value $\left(10^{-3} \mathrm{~S}^{-1}\right)$} \\
\cline { 2 - 3 } & $\mathrm{K}_{1}$ & $\mathrm{~K}_{2}$ \\
\hline $\mathrm{B}=0$ & 13.91 & 0.11 \\
$\mathrm{~B}=0.5$ & 13.86 & 0.75 \\
$\mathrm{~B}=0.8$ & 18.89 & 0.82 \\
$\mathrm{~B}=1$ & 17 & 0.61 \\
$\mathrm{~B}=1.2$ & 15.78 & 0.74 \\
$\mathrm{~B}=1.5$ & 1.01 & 0.11 \\
$\mathrm{~B}=1.8$ & 1.04 & 0.09 \\
$\mathrm{~B}=2$ & 0.94 & 0.11 \\
$\mathrm{~B}=2.2$ & 0.99 & 0.12 \\
$\mathrm{~B}=2.5$ & 0.82 & 0.14 \\
$\mathrm{Al}_{13}$ & 0.87 & 0.87
\end{tabular}

in-homogenous neutralizing conditions. Usually, in the base titration situation, the Keggin- $\mathrm{Al}_{13}$ generally begins to appear at $\mathrm{pH}$ higher than 3.5.

Many experimental results demonstrated that the formation of Keggin- $\mathrm{Al}_{13}$ needs precursors of either dimer or trimer and especially tetrahedral aluminum species, which must be first produced in solution or added as external reagent. In the common condition of base titration, the strong base injection creates micro-interfaces of $\mathrm{pH}$ junction in acid aluminum solution. It thereby promotes the self-assembling of precursors from both sides. This reaction in nanometer scale is a forced hydrolysis derived by the abrupt shock of $\mathrm{pH}$. The resultants through forced hydrolysis would be an artificial outcome of Keggin- $\mathrm{Al}_{13}$ different from flat- $\mathrm{Al}_{13}$ produced by spontaneous hydrolysis.

\subsection{Dual-hydrolysis model}

A dual-hydrolysis model (Fig. 1) is proposed by comprehensive consideration of both the spontaneous and forced hydrolysis [1,33]. When forced hydrolysis takes place, the $\mathrm{pH}$ of the solution will be buffered to some extent and the presence of dimer or trimer which is required for Keggin- $\mathrm{Al}_{13}$ to be formed. The spontaneous hydrolysis must then be promoted to transfer based on the hydrolytic equilibrium. Consequently, during the base addition step, both of the two hydrolysis reactions would be pushed forward in solution parallel and exchanging their species. The artificial forced hydrolysis may interrupt the spontaneous equilibrium to compel the system to become a steady state.

Accordingly, the Keggin- $\mathrm{Al}_{13}$ clusters are the synthesized products from dual-hydrolysis processes. The dual-hydrolysis model can precisely describe the constitution and transfer pathways of the multiple reactions for $\mathrm{Al}(\mathrm{III})$ clusters in solution.

\section{Stability of Keggin- $\mathrm{Al}_{13}$ in PACl}

Owing to the steady $\mathrm{Al}(\mathrm{O})_{4}$ core, the Keggin- $\mathrm{Al}_{13}$ species in artificial $\mathrm{PACl}$ solution and after dosing to water exhibit high stability to maintain their structure and resist to further hydrolysis. That is different from the hydroxyl $\mathrm{Al}(\mathrm{O})_{6}$ species formed by alum or $\mathrm{AlCl}_{3}$ in spontaneous hydrolysis after dosing.

The results of speciation characterization at $\mathrm{PACl}$ dose of $2 \times 10^{-4} \mathrm{~mol} \mathrm{Al} / \mathrm{L}$ are summarized in previous publication [9]. It is indicative that $\mathrm{pH}$ has significant effect on further speciation transformation of $\mathrm{PACl}$ corresponding with the $\mathrm{OH} / \mathrm{Al}$ values. Further transformation of PACls species after dosing under various conditions depends largely on the original composition. The PACls at low $\mathrm{OH} / \mathrm{Al}$ ratio exhibit a significant change of species under various conditions. While the high $\mathrm{OH} / \mathrm{Al}$ ratio PACls exhibits efficient speciation stability and tends to maintain the original speciation distribution. It shows also that the $\mathrm{Al}_{\mathrm{a}}$ fractions in the primary coagulants are the most labile species. After dosing, it would quickly transform into $\mathrm{Al}_{\mathrm{b}}$ and finally $\mathrm{Al}_{\mathrm{c}}$ depending

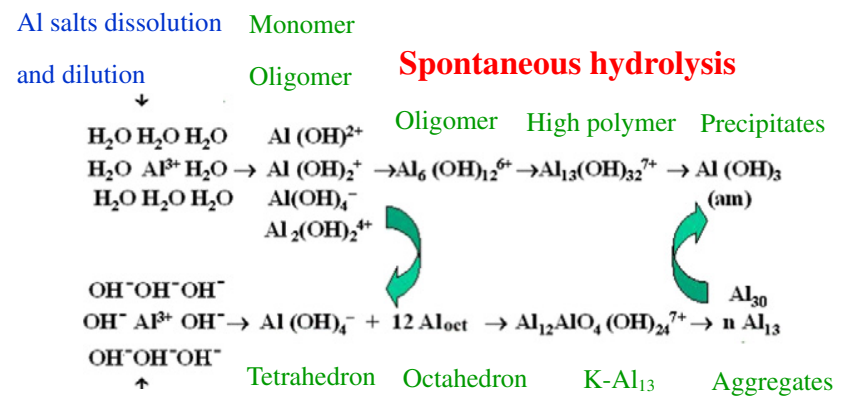

Micro envrinment

with strong alkali

Forced hydrolysis

Fig. 1. The dual-hydrolysis model of $\mathrm{Al}(\mathrm{III})$. 
on the reaction conditions. The polymeric and colloidal species, once preformed, are quite stable. In addition, the $\mathrm{Al}_{\mathrm{b}}$ and $\mathrm{Al}_{\mathrm{c}}$ species formed after dosing exhibit quite different nature with the preformed species as shown under further aging period [6,9].

A significant difference between the alum and PACls can also be observed. The traditional coagulant-alum, after dosing into water of middle $\mathrm{pH}$ range, is hydrolyzed to species containing mainly $\mathrm{Al}_{\mathrm{c}}$. They consist of sol and precipitates with low surface charge density. Their coagulation effects and mechanism are distinct from the PACl because the Keggin- $\mathrm{Al}_{13}$ clusters with stronger charge density can retain their conformation to affect the particulates directly.

New technologies to tailor-make $\mathrm{Al}_{13}$-PACl have been proposed and provide other direct verifications on the stability of $\mathrm{Al}_{13}$ [5,34-37]. The pure $\mathrm{Al}_{13}$ solutions can be prepared at high concentration, $2 \mathrm{~mol} \mathrm{Al} / \mathrm{L}$, which is similar concentration to the liquid industrial $\mathrm{PACl}$ products.

\section{Coagulation mechanism of hydroxy-aluminum clusters}

\subsection{Adsorption and surface coverage}

$\mathrm{PACl}$ and alum as coagulants adsorbed on particles via different species and mode. PACl with the Keggin- $\mathrm{Al}_{13}$ clusters adsorbed directly to particle surface by complexation and underwent further hydrolysis insitu on the surface hydroxyl sites. Their adsorption isotherm appeared to be the Langmuir type with monolayer formation due to the interrepulsion of the residual charges. Alum adsorbed mainly with the precipitated $\mathrm{Al}(\mathrm{OH})_{3}(\mathrm{am})$ by attraction and adhesion and neutralized the particles by their low charges. Their adsorption isotherm presents the Freundlich type of multi-layer formation with enormous amorphous precipitates [38].

The fractional surface coverage on particles along the coagulation course can be estimated by the ratio of adsorbed coagulant amounts to total surface sites on silica microspheres in suspension. The maximum surface coverage of $\mathrm{PACl}$ was around 0.4 , whereas surface coverage of alum accumulated enormously. Corresponding to the coagulation process, the optimum effects for $\mathrm{PACl}$ occurred at the coverage of only around 0.1 and the restabilization occurred long before the maximum coverage. As for the alum, the optimum coagulation appeared at coverage around $0.2 \sim 0.3$.

\subsection{Coagulation of silica microspheres suspension}

Based on the coagulation diagram, the alum exerted its function mainly by the low-charged $\mathrm{Al}(\mathrm{OH})_{3}(\mathrm{am})$ to cover the surface and adhere the particles with a combined actions of charge neutralization and sweeping sedimentation. The Keggin- $\mathrm{Al}_{13}$ clusters in $\mathrm{PACl}$ maintain their polycation structure to perform the surface complexation and deposition on particles and to aggregate them to form flocs. The distinct performances of coagulation between the two sorts of coagulants were investigated further by using several stoichiometric methods.

The suspensions of silica microspheres $(2 \sim 3 \mu \mathrm{m})$ were coagulated with alum and $\mathrm{PACl} 2.2$, respectively. The results are shown in the Fig. 2 [38]. The chemical speciation of the coagulants was identified both by Ferron assay and ${ }^{27} \mathrm{Al}$ NMR. The whole coagulation process was simulated by jar test with residual turbidity and zeta potential determination. The results showed that the optimum dosage for $\mathrm{PACl}$ was achieved at $1 \sim 2 \mu \mathrm{mol} / \mathrm{L}$ before the IEP but the restabilization appeared after overdosing. The optimum dosage for alum was 4 5 times of that for PACl but appeared just around IEP and no restabilization occurred with overdose.

\subsection{Microfloc aggregation and simplified DLVO simulation}

The hydroxyl aluminum clusters exhibited significant difference on microfloc formation and the aggregation kinetic behaviors. The increasing volumes of microfloc via aggregation were observed by the PDA system and their fractal dimensions were calculated based on static laser scattering absorption. The investigation was carried out under the conditions of three different dosages. Under the low dosage of $10^{-6} \mathrm{~mol} / \mathrm{L}$, the $\mathrm{PACl}$ microfloc aggregated rapidly to form compact flocs, but the alum microflocs remained unchanged. Under the higher dosage of $10^{-5} \mathrm{~mol} / \mathrm{L}$, the $\mathrm{PACl}$ particulates aggregated slowly but the alum floc enlarged very fast. Under the high overdosing condition of $10^{-4} \mathrm{~mol} / \mathrm{L}$, the PACl flocs started to be dispersed due to restabilization, and the alum flocs became voluminous.

The traditional DLVO theory is an ideal and multi-factorial model for the estimation of potential energy between homological particles. Its pertinent application to coagulation of aquatic particulates could be only at a simplified simulation level. The calculation scene would be the interaction potentials between the particulates charged with preliminary adsorbed coagulants in the step to form the microflocs. The resulted integrated potential curves showed that beyond the fade away of the potential peak, the second minimum appeared at about $20 \mathrm{~nm}$ of distance between particles. When the second minimum of potential achieved to the deep over $10 \mathrm{kT}$, the particulates can be effectively aggregated through the dominated attractive potential.

The simulated results from the various concentrations of aluminum were closely corresponding to the dosage in coagulation test for both coagulants, respectively.

\subsection{Morphological observation}

The microfloc of purified Keggin- $\mathrm{Al}_{13}$ under atomic force microscope is a branched chain as shown in Fig. 3. Their units are at the nanometer scale.

The electromicroscopy images showed that the microflocs made by $\mathrm{PACl}$ at low optimum dosage are patched bridging aggregates and that at overdose are dispersed away particles. On the other hand, the microflocs coagulated by alum at the same low dosage remained like single particulates but transformed to enormous sweeping flocs at overdose.

By using the colloid probe microscopy, it was observed more microcosmically. The images looked like flocs that assumed patched and covered models, respectively.

\subsection{Coagulation calculation model}

According to above studies, it was demonstrated that the coagulation mechanism between alum and $\mathrm{PACl}$ are distinctly different mainly due to their chemical speciation and structural stability to $\mathrm{pH}$ and other factors in solution after dosing.

The $\mathrm{PACl}$ dominated by Keggin- $\mathrm{Al}_{13}$ clusters persisted to remain their artificially produced structure and adsorbed to particles via surface complexation. On the surface, they may be hydrolyzed further in the reaction with surface $\mathrm{OH}$ groups to build patches there. The high charged $\mathrm{Al}_{13}$ may neutralize simultaneously more particles with their residual charges and link them with electro-patches into aggregates and microflocs to be removed. Sometimes, these strong charged clusters trend to promote the restabilization of particles during overdosing.

After dosing, the alum dissolved and spontaneously hydrolyzed to form $\mathrm{Al}(\mathrm{O})_{6}$ octahedral series species. They may exist as oligomers or clusters with pure double $\mathrm{OH}$ linkage structures and easily transformed to sol and precipitates under the conditions of around the netural $\mathrm{pH}$ range and common $\mathrm{Al}$ dosage. The low charged amorphous precipitates may be adsorbed or adhered to particles, neutralize them and cover on their surface to form microflocs. They can further bundle more particles to make enormous flocs and sweep up other pollutants.

The PACl coagulants can coagulate and flocculate pollutants in water treatment process more economically (lower dosage) than alum. However, they require more accurate dosing in operation to avoid 

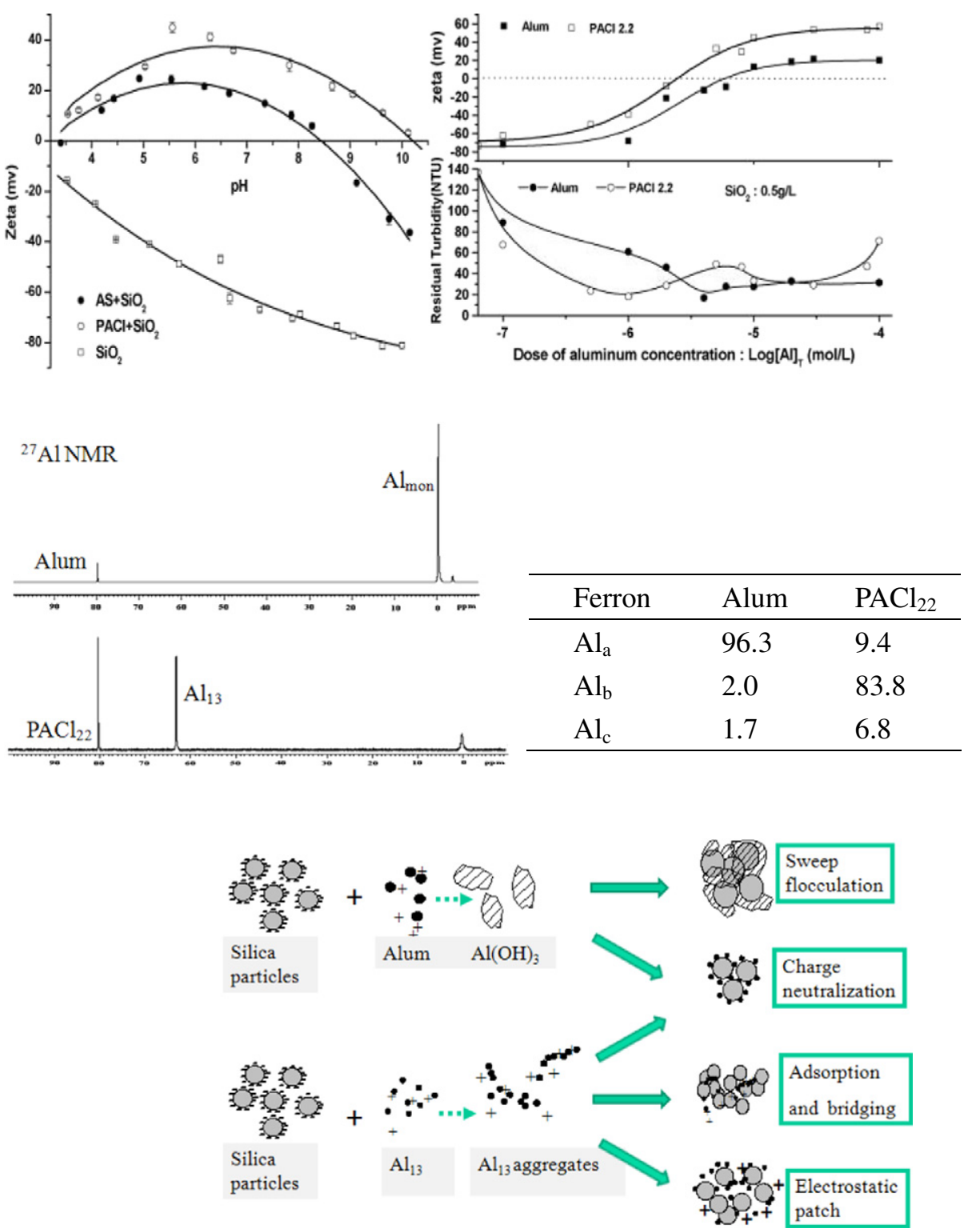

Fig. 2. Mechanistic difference of coagulation of silica microspheres with alum and $\mathrm{PACl} 2.2$.

restabilization. Therefore, a quantitative model of coagulation with inorganic polymer flocculants was developed by using $\mathrm{PACl}$ as an example. Application of a modified precipitation charge-neutralization model (M-PCNM) was examined and discussed, including variation of dose, $\mathrm{pH}$, and $B$ value on the resulting coagulation diagram. The model was improved by using measured $\mathrm{Al}$ fractions as model inputs. The experimental results showed that there exists a remarkable difference in coagulation with various $\mathrm{PACl}$ formulations in accordance with the different species being performed. This indicates that the assumption of all the surface species consisting of the same aluminum hydroxide solids is not correct, and some modification of the PCNM is therefore needed. By invoking different final hydroxide precipitates, the M-PCNM can be used quite well to predict the general behavior of coagulation with IPF-PACl (Fig. 4). In addition, they cannot exert their superiorities completely in traditional water treatment reactors that were designed mainly for alum to form bulky flocs to facilitate sedimentation. The water treatment technologies more compatible to tailor-made $\mathrm{PACl}$ coagulants would be the surface contact coagulation units like microfloc filtration, flotation, membrane and fiber separation, etc.

\section{Conclusions}

The relative importance of three different $\mathrm{Al}$ species $\left(\mathrm{Al}_{\mathrm{a}}, \mathrm{Al}_{\mathrm{b}}, \mathrm{Al}_{\mathrm{c}}\right)$ defined by timed complexation reaction rate measured by using ferron reagent in polyaluminum chloride ( $\mathrm{PACl}$ ) was investigated in terms of DOC, $\mathrm{UV}_{254}$, and turbidity removal efficiencies. The results show that DOC removal is correlated well to the content of $\mathrm{Al}_{\mathrm{b}}$. Removal of $\mathrm{UV}_{254}$ is determined by the content of $\mathrm{Al}_{\mathrm{b}}$ and $\mathrm{Al}_{\mathrm{c}}$, particularly $\mathrm{Al}_{\mathrm{c}}$. $\mathrm{Al}_{\mathrm{a}}$ shows a strong ability to react with some unsatisfied coordinate bonds of organic matter to facilitate particle and DOC removal [17]. The fraction distributions of NOM and residual $\mathrm{Al}$ after coagulation in solution, colloid, and sediment were analyzed as changes of coagulant dosage and $\mathrm{pH}$. Medium polymerized $\mathrm{Al}$ species $\left(\mathrm{Al}_{\mathrm{b}}\right)$ can destabilize particle and NOM efficiently, while some flocs formed by Alb are not large and not easy to precipitate as compared to those formed by colloidal of solid $\mathrm{Al}$ species $\left(\mathrm{Al}_{\mathrm{C}}\right)$. Thus, $\mathrm{Al}_{\mathrm{c}}$ could adsorb and remove NOM efficiently [39].

As shown by the many examples covered in this review, different hydroxyl aluminum had different coagulation mechanisms. The species 

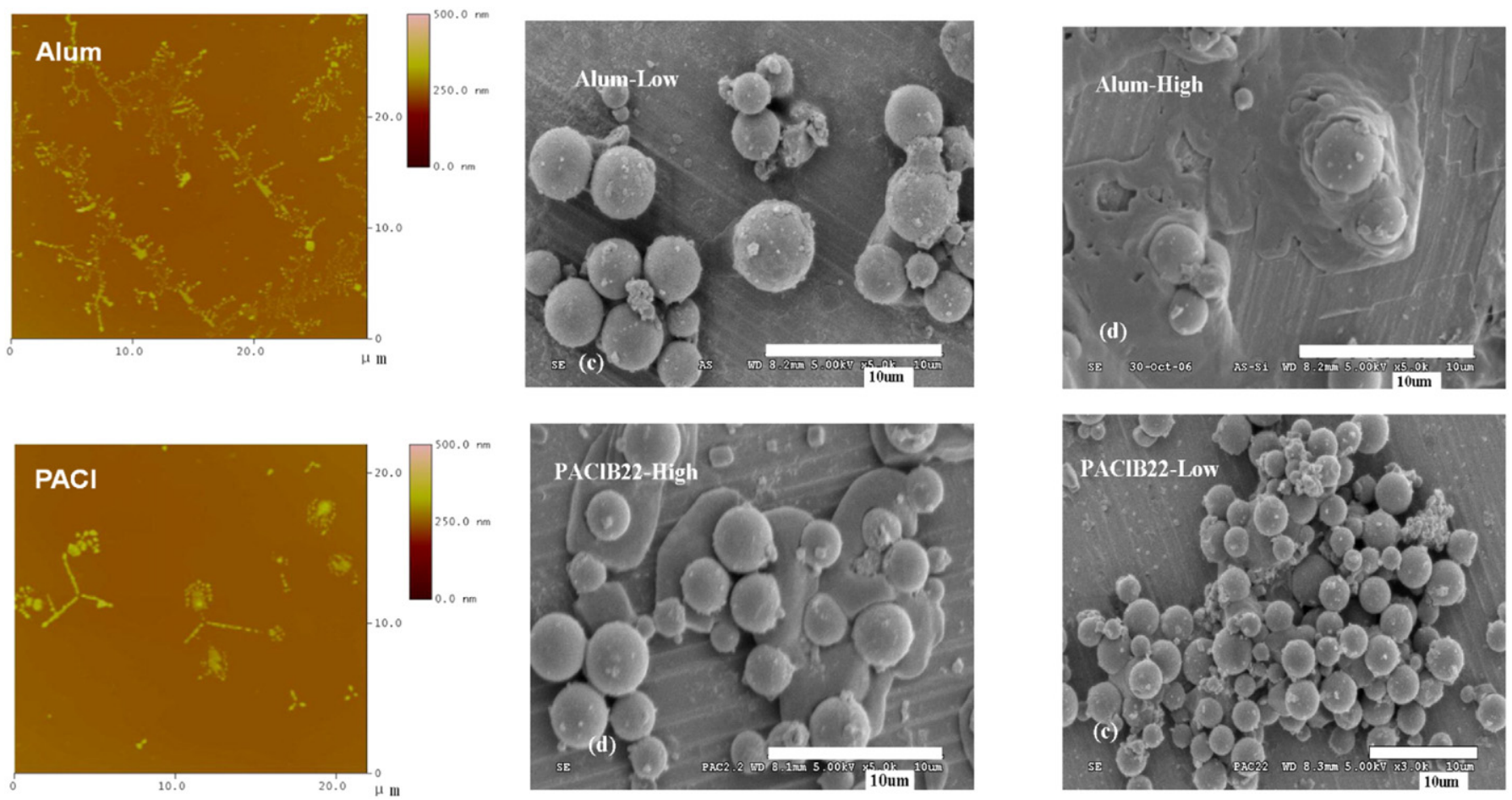

Fig. 3. The microphological observation of the floc formation: 1) AFM; 2) TEM; 3) CPM.

formation, stability, and transformation of various hydrolyzed aluminum clusters were complicate. Many of technologies were used to analyze the chemical speciation of hydroxyl aluminum clusters, and different hydrolysis pathways of aluminum salts in aqueous solution were presented to better understand the Al speciation distribution. But the hydrolysis pathway of aluminum salts in aqueous solution was speculative that need more laboratory proofs. The stability of Keggin$\mathrm{Al}_{13}$ was affected by solution $\mathrm{pH}$, and the $\mathrm{PACls}$ at low $\mathrm{OH} / \mathrm{Al}$ ratio exhibit a significant change of species under various conditions, while the high $\mathrm{OH} / \mathrm{Al}$ ratio PACls exhibit efficient speciation stability and tend to maintain the original speciation distribution. The alum exerted its function mainly by the low-charged $\mathrm{Al}(\mathrm{OH})_{3}$ to cover the surface and adhere the particles with a combined actions of charge neutralization and sweeping sedimentation. Keggin- $\mathrm{Al}_{13}$ clusters in $\mathrm{PACl}$ maintain their polycation structure to perform the surface complexation and deposition on particles and to aggregate them to form flocs. The microfloc of purified Keggin- $\mathrm{Al}_{13}$ under atomic force microscope is a branched chain, and their units are at the nanometer scale.

\section{Acknowledgement}

This work was supported by the National Basic Research Program of China (Grant No. 2011CB933704) and the National Natural Science Foundation of China (Grant Nos. 51338010, 51221892, 51025830, and 50921064). The continuous contributions from the graduated students are greatly appreciated, to name a few of them such as Bi Z, Yan MQ Feng CH, Wu XH, Xu H, Ye CQ, Wang SF, Jiao RY, Li T, Gao Q Xu Y, etc.
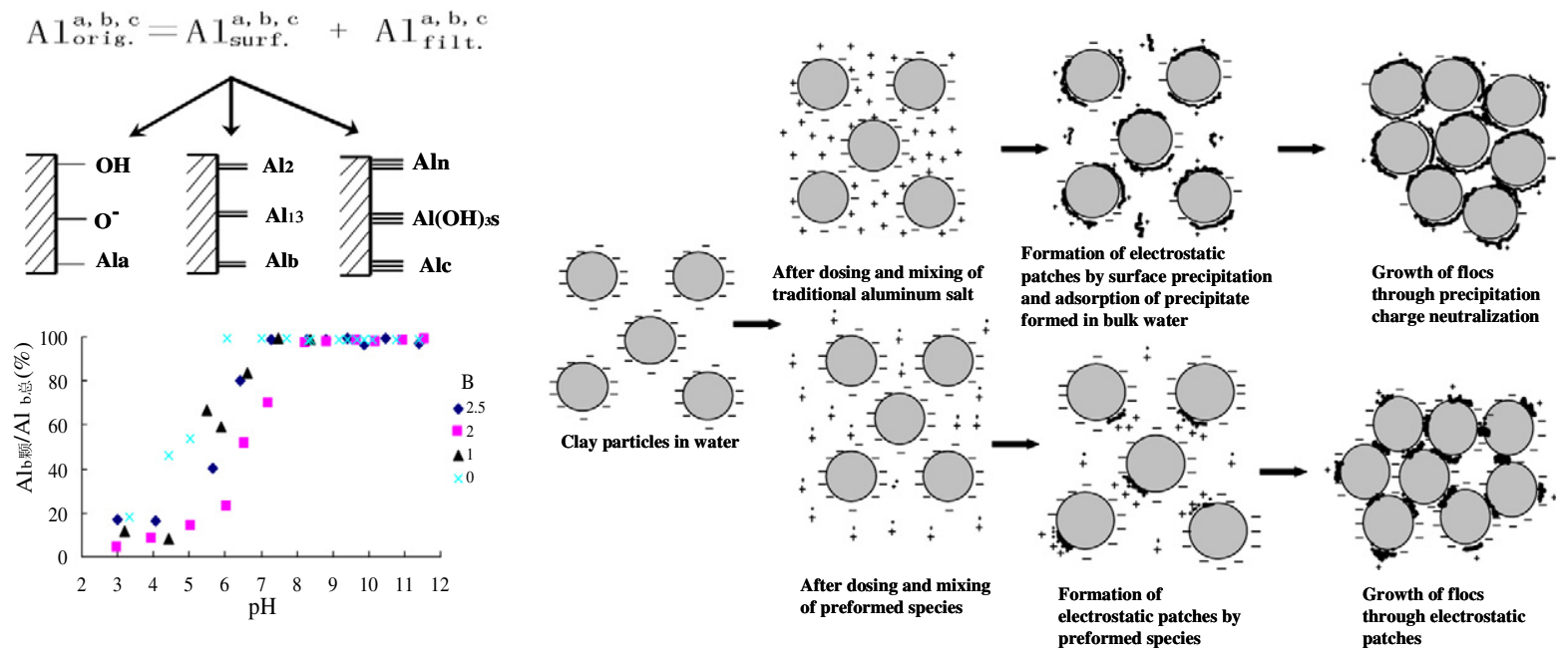

Fig. 4. Micro-interface model and patch coagulation schematic chart. 


\section{References}

[1] Tang HX. Inorganic polymer flocculants and flocculation theory. Beijing: China $\mathrm{Ar}-$ chitecture and Building Press; 2006(in Chinese).

[2] Bertsch PM. The environmental chemistry of aluminum. N.Y: CRC Press; 1996

[3] Teagarden DL, Kozlowski JF, White JL, Hem SL. J Pharm Sci 1981;70:758-61.

[4] Pinnavia TJ. Science 1983;220:365-71.

[5] Van Benschoten J, Edzwald JK. Water Res 1990;24(12):1519-26.

[6] Wang DS, Wu XH, Huang L, Tang HX. Chemical water and wastewater treatment, IX; IWAIn: Hahn HH, Odegaard H, editors. ; 2007. p. 181-8.

[7] Wang DS, Tang HX, Gregory J. Environ Sci Technol 2002;36(8):1815-20.

[8] Parker DR, Bertsch PM. Environ Sci Technol 1992;26:908-14.

[9] Wang DS, Sun W, Xu Y, Tang HX, Gregory J. Colloids Surf A Physicochem Eng Asp 2004;243:1-10.

[10] Kloprogge JT, Seykens D, Jansen JBH, Geus JWA. Non-Cryst Solids 1992;142:94-102.

[11] Dentel SK. Environ Sci Technol 1988;22(7):825-32.

[12] Lartiges BS, Bottero JY, Derrendinger LS, et al. Langmuir 1997;13(2):147-52.

[13] Duan JM, Gregory J. Adv Colloid Interface Sci 2003;100:475-502.

[14] Chowdhury ZK, Amy GL. Environ Sci Technol 1991;25:1766-73.

[15] Letterman RD, Asolekar SR. Water Res 1990;24:931-9.

[16] Dentel SK, Gossett JM. J Am Water Works Assoc 1988;80:187-98.

[17] Yan MQ, Wang DS, Qu JH, He WJ, Chow CWK. J Colloid Interface Sci 2007;316(2): $482-9$.

18] Wang DS, Tang HX. J Environ Eng 2006:132:434-41.

[19] Bottero JY, Cases JM, Fiessinger F, Poivier JE. J Phys Chem 1980;84:2933-9.

[20] Hu CZ, Liu HJ, Qu JH, Wang DS, Ru J. Environ Sci Technol 2006;40:325-31.
[21] Lin JL, Huang CP, Pan JR, Wang DS. Chemosphere 2008;72:189-96.

[22] Wang Y, Gao BY, Xu XM, Xu WY, Xu GY. J Colloid Interface Sci 2009;332:354-9.

[23] Xu WY, Gao BY, Yue QY, Wang Q. Sep Purif Technol 2001;78:83-90.

[24] Casey WH. Chem Rev 2006;106:1-16.

[25] Allouche L, Gerardin C, Loiseau T, Taulelle F. Angew Chem Int Ed 2000;39(3):511-4.

[26] Feng CH, Bi Z, Tang HX. Environ Sci Technol 2015;49:474-80.

[27] Bi Z, Feng CH, Wang DS, Ge XP, Tang HX. Colloids Surf A Physicochem Eng Asp 2012; 407:91-8.

[28] Sun Z, Wang H, Feng H, Zhang Y, Du S. Inorg Chem 2011;50(19):9238-42.

[29] Sun Z, Wang H, Tong H, Sun S. Inorg Chem 2010;50(2):559-64.

[30] Ye CQ, Wang DS, Wu XH, Qu JH. J Colloid Interface Sci 2009;335:44-9.

[31] Wu XH, Ye CQ, Wang DS, Ge XP, Tang HX. Water Sci Technol 2009;59:815-22.

[32] Feng CH, Shi BY, Wang DS, Li GH, Tang HX. Colloids Surf A Physicochem Eng Asp 2006;287:203-11.

[33] Feng CH, Tang HX, Wang DS. Colloids Surf A Physicochem Eng Asp 2007;305:76-82.

[34] Tang HX, Wang DS, Xu Y. Chemical water and wastewater treatmentIn: Hahn HH, Odegaard H, editors. ; 2004. p. 139-49 (VIII, IWA).

[35] Liu HJ, Qu JH, Hu CZ, Zhang SJ. Colloids Surf A Physicochem Eng Asp 2003;216: 139-47.

[36] He F, Wang PJ, Jia ZQ Liu ZZ. J Membr Sci 2003;227:15-21.

[37] Wang D, Wang S, Huang C, Chow CWK. J Environ Sci 2011;23(5):705-10.

[38] Wu XH, Ge XP, Wang DS, Tang HX. Colloids Surf A Physicochem Eng Asp 2007;305: 89-96.

[39] Yan MQ, Wang DS, Ni JR, Qu JH, Chow CWK, Liu HJ. Water Res 2008;42:3361-70. 